\title{
Effects of raw milk and starter feed on intake and body composition of Holstein $\times$ Gyr male calves up to 64 days of age
}

\author{
A. L. Silva, ${ }^{* 1}$ M. I. Marcondes, ${ }^{*}$ E. Detmann, ${ }^{*}$ F. S. Machado,† S. C. Valadares Filho, ${ }^{*}$ A. S. Trece, ${ }^{*}$ \\ and J. Dijkstrał \\ *Department of Animal Science, Universidade Federal de Viçosa, 36570-000 Viçosa, Minas Gerais, Brazil \\ †Empresa Brasileira de Pesquisa Agropecuária (EMBRAPA), 36038-330 Juiz de Fora, Minas Gerais, Brazil \\ $\ddagger$ Animal Nutrition Group, Wageningen University, PO Box 338, 6700 AH Wageningen, the Netherlands
}

\section{ABSTRACT}

The objective was to evaluate the effect of supplying different levels of raw milk, alone or in combination, with access to a starter feed, on the intake, digestibility, daily gain, $\mathrm{N}$ balance, and body composition of Holstein $\times$ Gyr crossbred suckling calves until $64 \mathrm{~d}$ of age. Thirty-nine male calves aged $4 \mathrm{~d}$ with an average initial live weight of $36 \pm 1.0 \mathrm{~kg}$ were used. Five calves were defined as a reference group and slaughtered at 4 $\mathrm{d}$ of age to estimate the initial body composition of the animals. The other calves were distributed according to a completely randomized design in a $3 \times 2$ factorial arrangement consisting of 3 levels of milk $(2,4$, or 8 $\mathrm{L} / \mathrm{d}$ ) and 2 levels of starter feed (presence or absence in diet). At 15 and $45 \mathrm{~d}$ of age, 4 animals from each treatment were subjected to digestibility trials with total collection of feces and urine and sampling of feeds. At $64 \mathrm{~d}$ of age, all animals were slaughtered and their body tissues were sampled for analyses. Total dry matter and nutrient intake increased linearly and starter intake decreased linearly in response to the supply of increasing amounts of milk. The digestibility coefficient of organic matter was not affected by the inclusion of starter feed and increased linearly as milk supply was elevated. Daily gain was greater at increased milk supply levels and also greater when starter was supplied, without any interaction between milk supply level and the presence or absence of starter. Fecal $\mathrm{N}$ excretion and $\mathrm{N}$ retention were higher in the animals fed starter feed. Fecal N excretion was not affected by milk levels, whereas $\mathrm{N}$ retention was affected. Body protein and ash contents decreased linearly according to increased milk allowance. In contrast, fat body content increased linearly according to milk supply. The presence of starter feed in the diet was responsible for the increased body fat content, but had no effect on protein or ash content.

Received September 9, 2014.

Accepted December 27, 2014.

${ }^{1}$ Corresponding author: alex.lopes@ufv.br
In conclusion, weight gain and $\mathrm{N}$ retention in calves up to $64 \mathrm{~d}$ of age increased with milk supply. Ad libitum access to starter further increased weight gain and $\mathrm{N}$ retention and no interaction with milk allowance level occurred. However, greater levels of milk are also associated with reduced starter feed intake, in addition to increased body fat content.

Key words: fat deposition, performance, protein deposition

\section{INTRODUCTION}

In the last few years, there has been increasing interest in replacement calves feeding practices during suckling phase with a view to increasing weight gain and reaching puberty faster to improve the profitability of milk-production systems (Bach, 2012; Piantoni et al., 2012). In this sense, several strategies have been used to accelerate the growth rate of calves during the suckling phase, such as supplying of greater amounts of milk or altering milk replacer composition, aiming to increase nutrient intake by animals. Responses obtained according to these hypotheses are very positive in that they provide improvements in the performance of animals not only in suckling phase, but also during postweaning and lactation phases (Moallem et al., 2010; Khan et al., 2011; Soberon et al., 2012; Miller-Cushon et al., 2013). Another aspect of relative importance to increase performance during the suckling phase is the supply of a starter feed, which is aimed at increasing the intake of nutrients, in addition to being used as a strategy to promote the development of ruminal papillae and adapting the animals to solid diets that will be used subsequent to their weaning (Khan et al., 2007a; Silper et al., 2014).

The vast majority of research results available in the literature are from experiments with concurrent use of milk or milk replacer and a starter feed. Usually, solid feed intake of calves decreases with increased milk allowance (Jasper and Weary, 2002; Bach et al., 2013), but starter intake may also increase with increased milk allowance (Kristensen et al., 2007). Although this prac- 
tice represents commercial rearing conditions accurately, it limits the understanding of the separate effects of milk and starter feed (Hill et al., 2008). Therefore, it is not possible to determine whether variation occurring in certain variables (e.g., intake, digestibility, retention of nutrients) result from milk or from starter feed or to understand possible interactions among them taking into account concepts regarding the supply of larger quantities of milk.

Based on the hypothesis that variables related to intake and performance of calves respond differently to the presence or absence of a starter feed in diet and the fact that they are also dependent on the quantity of milk supplied, and in view of the clear need for information on this subject, our study was designed to evaluate the effect of supplying different amounts of milk, alone or in combination with access to a starter feed, on intake, digestibility, performance, $\mathrm{N}$ balance, and body composition of Holstein $\times$ Gyr crossbred suckling calves until $64 \mathrm{~d}$ of age.

\section{MATERIALS AND METHODS}

The experiment was approved by the Ethics Committee on Animal Use of Universidade Federal de Viçosa (Viçosa, MG, Brazil), under protocol no. 049/2012.

\section{Animals, Treatments, and Feeding}

The animals originated from the José Henrique Bruschi Experimental Field, belonging to Empresa Brasileira de Pesquisa Agropecuária (Embrapa Dairy Cattle). Immediately after birth, calves were separated from their respective mothers, weighed, and identified. Navel disinfection was performed with $7 \%$ iodine solution. Three liters of colostrum were supplied within 2 $\mathrm{h}$ of birth and $3 \mathrm{~L}$ were supplied $12 \mathrm{~h}$ after the first feeding. On the second and third days of life, all calves received $6 \mathrm{~L}$ daily of colostrum or transition milk. After the third day, the animals were transported to Universidade Federal de Viçosa, where they were housed in individual stalls and subjected to treatments.

Thirty-nine uncastrated crossbred male calves were used $(1 / 2$ to $3 / 4$ Holstein $\times$ Gyr $)$ with an average initial BW of $36 \pm 1.0 \mathrm{~kg}$. All animals were from a fixed-time insemination protocol that proportioned an amplitude maximum of $8 \mathrm{~d}$ between all births. In total, 5 animals were used as a reference group and were slaughtered at $4 \mathrm{~d}$ of age and analyzed for body composition as described herein. The other calves were distributed according to a completely randomized design in a $3 \times 2$ factorial arrangement consisting of 3 levels of milk and 2 levels of starter feed. Thus, 6 treatments were formed: $2 \mathrm{~L}$ of milk daily $(\mathbf{2} \mathbf{L} ; \mathrm{n}=4) ; 4 \mathrm{~L}$ of milk daily $(\mathbf{4} \mathbf{L} ; \mathrm{n}$
Table 1. Components used in starter formulation (DM basis) and chemical composition of starter feed and milk

\begin{tabular}{lcc}
\hline Item & Starter & Milk \\
\hline Composition $(\mathrm{g} / \mathrm{kg})$ & & \\
Soybean meal & 324.9 & - \\
Corn meal & 626.4 & - \\
Wheat bran & 30.94 & - \\
Dicalcium phosphate & 3.03 & - \\
Limestone & 11.23 & - \\
Sodium chloride & 2.37 & - \\
Mineral premix & 1.21 & - \\
Chemical composition $(\mathrm{g} / \mathrm{kg})$ & & \\
DM $^{2}$ & 892.2 & 114.0 \\
$\mathrm{OM}^{3}$ & 959.8 & 937.4 \\
$\mathrm{CP}^{3}$ & 191.5 & 256.6 \\
Ether extract $^{3}$ & 25.5 & 285.0 \\
NDFap $^{3,4}$ & 130.7 & - \\
NFC $^{3}$ & 611.0 & 395.8 \\
\hline
\end{tabular}

${ }^{1}$ Content $(\mathrm{g} / \mathrm{kg})$ : zinc sulfate, 180.0; copper sulfate, 150.0; cobalt sulfate, 10.0; sodium selenite, 10.0; potassium iodate, 10.0.

${ }^{2}$ As fed basis.

${ }^{3} \mathrm{DM}$ basis.

${ }^{4} \mathrm{NDFap}=\mathrm{NDF}$ corrected for ash and protein.

$=6) ; 8 \mathrm{~L}$ of milk daily $(\mathbf{8 L} ; \mathrm{n}=6) ; 2 \mathrm{~L}$ of milk daily and ad libitum access to a starter feed $(\mathbf{2} \mathbf{L}+\mathbf{S} ; \mathrm{n}=6)$; $4 \mathrm{~L}$ of milk daily and ad libitum access to starter feed (which was supplied as meal form; $\mathbf{4} \mathbf{L}+\mathbf{S} ; \mathrm{n}=6$ ); and $8 \mathrm{~L}$ of milk daily and ad libitum access to starter feed $(\mathbf{8 L}+\mathbf{S} ; \mathrm{n}=6)$. Milk was supplied to animals, using pails, in 2 daily meals at $0600 \mathrm{~h}$ and $1500 \mathrm{~h}$, whereas starter feed (only for treatments that contained it) and water were available to animals ad libitum (Table 1).

\section{Digestibility Trials and Sampling}

At 15 and 45 d of life, 4 animals from each treatment were subjected to digestibility trials with total collection of feces for $72 \mathrm{~h}$ and urine for $24 \mathrm{~h}$ (Barbosa et al., 2006). The urine was collected by collecting funnels adapted to the penile region of the animals and coupled to polyethylene hoses that directed the urine to tanks kept in Styrofoam boxes with ice (Knowlton et al., 2010). After $24 \mathrm{~h}$ of collection, some animals showed high levels of stress and had diarrhea; thus, in these cases, only the data of the first day were used. At the end of each day of feces collection, total feces per calf were weighed, homogenized, and sampled. Total urine produced was quantified by weighing and measuring the volume, and two 50-mL aliquots were sampled. During the digestibility trial, milk and starter feed were also sampled.

\section{Slaughter}

At the end of the experiment, all animals were slaughtered after being deprived of solid food for $14 \mathrm{~h}$. Calves 
were stunned by brain concussion, which was followed by jugular venipuncture for total bleeding. After the bleeding procedure, blood was weighed and sampled. Subsequently, components of the gastrointestinal tract (rumen, reticulum, omasum, abomasum, and small and large intestines) were washed and weighed to quantify the empty body weight (EBW). Next, rumen, reticulum, omasum, abomasum, small and large intestines, internal fat, mesentery, liver, heart, kidneys, lung, tongue, spleen, diaphragm, esophagus, trachea, and reproductive tract were ground in an industrial grinder to make a composite and homogeneous sample of organs and viscera. Hides were weighed, ground, and sampled. Likewise, paws and the head were weighed and ground in an industrial bone grinder. A composite sample of blood, hides, head and paws, and organs and viscera was formed. The contribution of each of these components in the sample was proportional to the weight of respective component in the animal EBW. This sample was ground for approximately $20 \mathrm{~min}$ in an industrial grinder and then named "noncarcass components."

The carcass of each animal was divided into 2 halves, which were weighed and then conditioned in a cold room at $4^{\circ} \mathrm{C}$ for approximately $24 \mathrm{~h}$. After this period, carcasses were weighed and each right half-carcass was completely ground in an industrial grinder, forming a sample of "carcass components." The slaughter procedure for the reference group was similar to that adopted for other animals, and the average ratio obtained between EBW and live weight of the reference group was used to estimate the initial EBW of animals that continued to be fed.

\section{Chemical Analysis and Calculations}

Samples of feces were partially dehydrated in a forced-ventilation oven $\left(55^{\circ} \mathrm{C}\right)$ for $72 \mathrm{~h}$ and subsequently ground to $1 \mathrm{~mm}$. Samples of milk and body components, in turn, were partially dehydrated by lyophilization and ground to $1 \mathrm{~mm}$ in a knife mill (Detmann et al., 2012). Samples of feeds, feces, and body components were evaluated for their DM, ash, and CP contents according to AOAC International (1995) and ether extract (EE) according to AOCS (2009). Samples of feces and starter feed were also evaluated for NDF content corrected for ash and protein (NDFap; Detmann et al., 2012). One aliquot of urine was used to evaluate the total N content (AOAC International, 1995), whereas another was transferred to a private laboratory to determine the concentration of urine urea $\mathrm{N}$, according to Talke and Schubert (1965). Nonfibrous carbohydrates were calculated according to Detmann and Valadares Filho (2010) as

$$
\mathrm{NFC}=1,000-(\mathrm{CP}+\mathrm{NDFap}+\mathrm{EE}+\mathrm{CA}),
$$

where $\mathrm{CA}=$ crude ash and all values are in grams per kilogram.

The concentration of digestible energy (DE) of the diet was calculated by multiplying the digestible fraction of each caloric component by its respective energy value (NRC, 2001) as

$$
\begin{gathered}
\mathrm{DE}=(5.6 \times \mathrm{dCP})+(9.4 \times \mathrm{dEE})+(4.2 \times \mathrm{dNFC}) \\
+(4.2 \times \mathrm{dNDFap}),
\end{gathered}
$$

where $\mathrm{DE}$ is in megacalories per kilogram; $\mathrm{dCP}=$ digestible $\mathrm{CP}$ concentration $(\mathrm{kg} / \mathrm{kg}) ; \mathrm{dEE}=$ digestible EE concentration $(\mathrm{kg} / \mathrm{kg}) ; \mathrm{dNFC}=$ digestible NFC concentration $(\mathrm{kg} / \mathrm{kg})$; and dNFDap = digestible NDFap concentration $(\mathrm{kg} / \mathrm{kg})$.

The final body composition of animals was calculated as

$$
\mathrm{BC}_{\mathrm{y}}=\frac{\mathrm{C}_{\mathrm{y}}}{\mathrm{EBW}_{\mathrm{f}}} \times 100,
$$

where $\mathrm{BC}_{\mathrm{y}}=$ body composition of protein, fat, or ash (\% on DM basis); $\mathrm{C}_{\mathrm{y}}=$ protein, fat, or ash constituent in the final EBW $(\mathrm{kg})$; and $\mathrm{EBWf}=$ final $\mathrm{EBW}(\mathrm{kg})$.

\section{Statistical Analyses}

All statistical analyses were carried out by ANOVA using the PROC MIXED procedure of SAS Institute (2008). Experimental design was completely randomized in a $2 \times 3$ factorial arrangement: with and without supply of a starter feed; 2, 4, or $8 \mathrm{~L}$ of milk daily; and interaction between these fixed effects. Because of milk as a fixed supply, treatments without starter were not included in the analysis of intake. To estimate the digestibility of the starter feed, a linear equations system was set up considering the digestibility obtained for the diets with and without starter feed and the average ratio between milk and starter feed on the basis of DM from the animals' diet. For intake, digestibility, and N-balance variables, 2 digestibility trials were carried out in 2 different ages (15 and $45 \mathrm{~d}$ of life), which were included in the experimental model as repeated measures. Denominator degrees of freedom were estimated using the Kenward-Roger approximation. The selection of the (co)variance matrix was based on the corrected Akaike information criterion, and the heterogeneous compound symmetry was chosen. Significance of treatment effects was declared at $P<0.05$. 


\section{RESULTS}

\section{Intake and Digestibility}

No interaction effect was observed $(P>0.05)$ between the age at which digestibility trials were conducted and intake and digestibility variables tested (data not shown). However, the age at which digestibility trials were conducted $(15$ or $45 \mathrm{~d})$ affected $(P$ $<0.05)$ DMI, starter DMI, total organic matter intake (OMI), starter OMI, and also the intake of CP, DE (Table 2), EE, NFC, and NDFap (data not shown). Total DMI $(\mathrm{kg} / \mathrm{d})$, as well as relative DMI of starter feed $(\mathrm{g} / \mathrm{kg}$ of $\mathrm{LW})$ was higher at 45 than at $15 \mathrm{~d}$ of age. Nutrient intake increased linearly $(P<0.05)$ as milk supply increased, except for starter DMI, starter OMI, and NDFap intake, which decreased linearly $(P<0.05)$ as milk allowance increased (Table 2; Figure 1).

Milk and starter feed digestibility were significantly different $(P<0.01)$, wherein the observed milk digestibility was $926 \mathrm{~g} / \mathrm{kg}$ and calculated starter feed digestibility was $779 \mathrm{~g} / \mathrm{kg}$. The age at which digestibility trials were carried out did not affect $(P>0.05)$ the digestibility of OM, NDFap (Table 2), CP, EE, or NFC (data not shown). Likewise, no effect of starter feed inclusion in diet or interaction between milk levels and starter feed was observed for any of digestibility measurements (data not shown). However, the digestibility of OM and NDFap, as well as other dietary components, increased $(P<0.05)$ with increased milk supply (Table 2$)$.

\section{Performance}

No interaction effect was observed $(P>0.05)$ between milk levels and starter feed inclusion for any of the performance measurements assessed (Table 3). Best performances (gain of various components) and feed efficiency were obtained by animals that received greater levels of milk, with hot and cold carcass yields being quadratically affected $(P<0.05)$ by milk level. Starter feed inclusion affected $(P<0.05)$ ADG, EBW, carcass components gain, and noncarcass components gain, but did not affect $(P>0.05)$ the hot and cold carcass yield and feed efficiency.

\section{Nitrogen Balance}

Nitrogen intake was higher at 45 than $15 \mathrm{~d}$ of age. Nitrogen intake linearly increased with milk supply and was greater in calves fed starter compared with calves fed milk only (Table 4). Fecal N excretion was greater for animals that consumed starter feed $(P<0.05)$ and it was not affected by milk levels $(P>0.05)$. The excretion of urine $\mathrm{N}$ and urinary urea $\mathrm{N}$ was not affected by

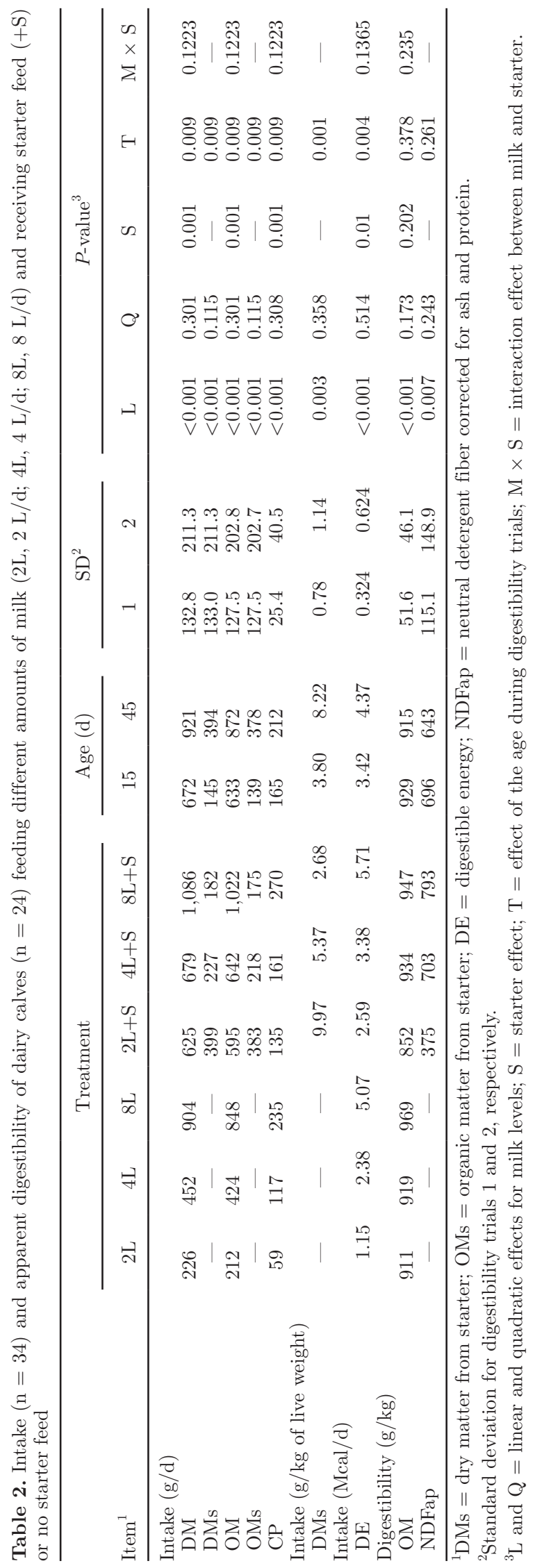


Table 3. Performance of dairy calves $(\mathrm{n}=34)$ feeding different amounts of milk $(2 \mathrm{~L}, 2 \mathrm{~L} / \mathrm{d} ; 4 \mathrm{~L}, 4 \mathrm{~L} / \mathrm{d} ; 8 \mathrm{~L}, 8 \mathrm{~L} / \mathrm{d})$ and receiving starter feed $(+\mathrm{S})$ or no starter feed

\begin{tabular}{|c|c|c|c|c|c|c|c|c|c|c|c|}
\hline Item $^{1}$ & \multicolumn{6}{|c|}{ Treatment } & SD & \multicolumn{4}{|c|}{$P$-value ${ }^{2}$} \\
\hline $\operatorname{ADG}(g / d)$ & 86 & 280 & 794 & 263 & 505 & 886 & 111.5 & $<0.001$ & 0.713 & $<0.001$ & 0.346 \\
\hline EBWG $(\mathrm{g} / \mathrm{d})$ & 60 & 242 & 744 & 211 & 467 & 794 & 109.5 & $<0.001$ & 0.956 & $<0.001$ & 0.164 \\
\hline CCG (g/d) & 24 & 148 & 458 & 102 & 268 & 502 & 70.8 & $<0.001$ & 0.991 & 0.003 & 0.432 \\
\hline CCY (g/kg) & 519 & 547 & 565 & 494 & 540 & 557 & 24.0 & $<0.001$ & 0.029 & 0.117 & 0.643 \\
\hline $\mathrm{FE}(\mathrm{kg} / \mathrm{kg})$ & 0.467 & 0.629 & 0.929 & 0.332 & 0.765 & 0.906 & 0.1581 & $<0.001$ & 0.061 & 0.1423 & 0.3943 \\
\hline
\end{tabular}

${ }^{1} \mathrm{EBWG}=$ empty body weight gain; $\mathrm{CCG}=$ carcass components gain; NCCG = non-carcass components gain; HCY = hot carcass yield; CCY $=$ cold carcass yield; $\mathrm{FE}=$ feed efficiency.

${ }^{2} \mathrm{~L}$ and $\mathrm{Q}=$ linear and quadratic effects for milk levels; $\mathrm{S}=$ starter effect; $\mathrm{M} \times \mathrm{S}=$ interaction effect between milk and starter.

milk level or starter supply. The greatest $\mathrm{N}$ retention values were shown by animals that ingested greater amounts of $\mathrm{N}$; this variable was influenced $(P<0.05)$ by milk levels and starter feed inclusion.

\section{Body Composition}

There was no interaction effect $(P>0.05)$ between milk level and starter feed inclusion on the final body composition of animals. Milk levels affected body content of protein and ash, showing a linear decrease, according to the increased milk allowance. In contrast, milk levels also linearly affected fat body content, showing an increase according milk supply.

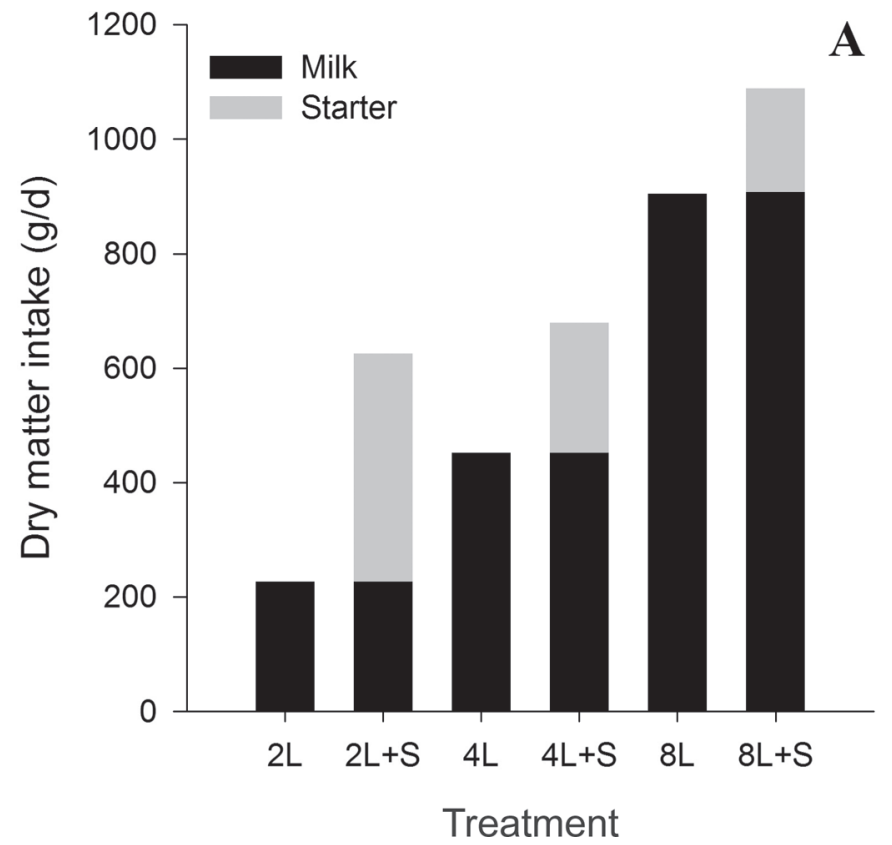

The supply of starter only affected fat body content, with greater fat content when starter was supplied compared with diets without starter, but starter had no effect on protein or ash content. Average daily gain of fat and protein was greater for animals that received starter feed and increased linearly with increased milk allowance.

\section{DISCUSSION}

\section{Intake and Digestibility}

The difference in intake at 15 versus $45 \mathrm{~d}$ of age reveals a strong correlation between the age of animals

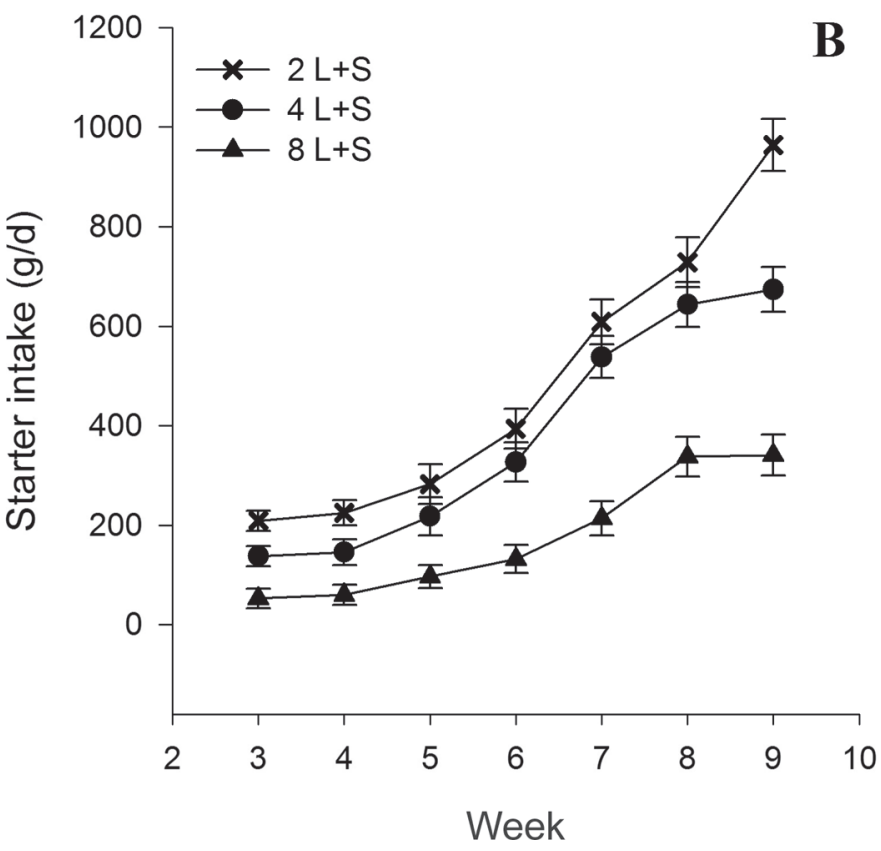

Figure 1. (A) Relationship between milk and starter (S) intake $(2 \mathrm{~L}=2 \mathrm{~L} / \mathrm{d} ; 4 \mathrm{~L}=4 \mathrm{~L} / \mathrm{d} ; 8 \mathrm{~L}=8 \mathrm{~L} / \mathrm{d})$, and (B) starter intake evolution according to treatments (error bars represent SE). 
and their capacity to ingest solid foods. However, this behavior is not simply related to an increase in the live weight of animals (see starter DMI as $\mathrm{g} / \mathrm{kg}$ of live weight in Table 2), but rather to the development of their gastrointestinal tract, which results in a low intake of solid feeds in the first weeks of life, regardless of the amounts of milk supplied (Table 2; Figure 1B). This emphasizes the importance of supplying appropriate amounts of milk to animals (Drackley, 2008; Bittar et al., 2009; Hill et al., 2013; Wenge et al., 2014).

The volume of milk supplied to animals also has a direct effect on starter feed intake and, consequently, on total DMI, especially in the first weeks of life (Kertz and Loften, 2013; Table 2; Figure 1B). The supply of high daily amounts of milk tends to restrict starter feed intake (Khan et al., 2007b; Sweeney et al., 2010; Hill et al., 2013; Miller-Cushon et al., 2013), which is probably due to the high circulating levels of glucose (Khan et al., 2011).

The increase in milk supply causes a greater intake of FA, which can elevate intestinal secretion of cholecystokinin, which in turn leads to a longer retention time of feed in the gastrointestinal tract and increases diet digestibility (Stanley et al., 2005). The increased digestibility with increased milk allowance may also be attributed to a lower dilution of fecal metabolic fraction for calves that received lower amounts of milk, which would result in a reduction in the apparent total-tract digestibility (Van Soest, 1994; Nascimento et al., 2010).

Although a difference between milk and starter feed digestibility was found (926 vs. $779 \mathrm{~g} / \mathrm{kg}$ ), no differences were observed between the digestibility of diets that contained starter feed and diets without starter feed. This fact can be linked to low starter feed intake in comparison to milk, which can cause a dilution effect on total diet digestibility. It was observed that the apparent digestibility of treatment $2 \mathrm{~L}+\mathrm{S}$ was numerically lower than $4 \mathrm{~L}+\mathrm{S}$ and $8 \mathrm{~L}+\mathrm{S}(852,934$, and $947 \mathrm{~g} / \mathrm{kg}$, respectively), reflecting differences between milk and starter feed digestibility; however, statistical differences were not observed.

\section{Performance}

Increased milk supply results in an increase in DMI (Table 2) and, consequently, increases the availability of nutrients to the animal, which is expected to result in improved performance (Table 3; Jasper and Weary, 2002; Khan et al., 2007b; Terré et al., 2009; MillerCushon et al., 2013). Similarly, an increase in nutrient intake was observed for animals that received starter feed over those fed milk only (Table 2). Thus, because 
no difference in digestibility was noted between the 2 groups (Table 2), more nutrients that could be metabolized were available for animals that received starter feed, which explains the better performance shown by this group.

Even when starter feed is offered to animals, low amounts of milk are responsible for low performances. In these cases $(2 \mathrm{~L}$ and $2 \mathrm{~L}+\mathrm{S})$, a low $\mathrm{EBW}$ can be observed (Table 3), and the great part of this gain is composed by organs and viscera gain, and not by tissue deposition on carcass. Low performances, when low amounts of milk are offered, reveal that calves are incapable of fully compensating nutrient deficits by increasing starter intake (Table 2; Kosiorowska et al., 2011). Feed efficiency was greater for animals that received large amounts of milk, as observed by Brown et al. (2005) and Diaz et al. (2001); this may be related with the level of intake above maintenance and with the greater intake of energy and protein (Table 2), as observed for calves that received higher amounts of milk (Blome et al., 2003).

\section{Nitrogen Balance}

Fecal $\mathrm{N}$ excretion has been suggested to be directly correlated with N intake (Véras et al., 2007; Santos et al., 2010). Fecal N excretion is apparently also correlated with the AA profile and diet texture, in as much as a greater excretion was seen for animals that consumed starter feed; this was not observed in the animals fed higher levels of milk.

Increased $\mathrm{N}$ intake has a positive correlation with $\mathrm{N}$ retention (Véras et al., 2007; Santos et al., 2010). This results in better $\mathrm{N}$ use efficiency, as when the intake is above maintenance level animals have more $\mathrm{N}$ available for deposition. Based on the $\mathrm{N}$ balance trial, $\mathrm{N}$ efficiency increased linearly with increased milk supply. However, when $\mathrm{N}$ intake is high, calves may approach their maximum protein deposition capacity (Gerrits et al., 1997) and the $\mathrm{N}$ efficiency may not increase further or even decrease. This effect was apparent when $\mathrm{N}$ efficiency was calculated based on observed protein gain. When starter was present in the diet, an increase in $\mathrm{N}$ intake from $2 \mathrm{~L}+\mathrm{S}$ to $4 \mathrm{~L}+\mathrm{S}$ increased $\mathrm{N}$ efficiency from 0.21 to 0.49 , but a further increase in $\mathrm{N}$ intake $(4 \mathrm{~L}+\mathrm{S}$ to $8 \mathrm{~L}+\mathrm{S})$ resulted in $\mathrm{N}$ efficiency of 0.48 . The $\mathrm{N}$ retention results based on the $\mathrm{N}$ balance differed from results based on difference in protein content of the body obtained with the slaughter technique. The largest differences between both methods occur at high milk supply levels. The relatively small increase in urinary $\mathrm{N}$ output with $\mathrm{N}$ intake, from 4 to $8 \mathrm{~L}$ of milk per day, indicates that some of the urinary $\mathrm{N}$ may have escaped during sampling and storage.

\section{Body Composition}

Increase in body fat deposition (Table 5) is linked to an increased energy intake by animals (Table 2), which was achieved when milk supply was increased and starter feed was included in the diet; similar behavior and values have been found by other authors (Bascom et al., 2007; Hill et al., 2008; Mills et al., 2010). The rapid growth rate in calves appears to be promising, but needs to be seen carefully, as body fat content has a negative relationship with parenchymal DNA in the mammary gland; this could have negative effects on milk production (Silva et al., 2002).

Although an increase in milk supply resulted in a greater $\mathrm{N}$ retention (Table 4 and 5 ), a decrease in body protein content was observed. This is likely related to the increased body fat content, which caused a dilution effect on protein content (Gerrits et al., 1997; Labussiere et al., 2008).

Similarly, inclusion of starter feed increased the N retention (Table 4 and 5), and animal performance (Table 3) but had no effect on body protein content. This fact may be related to the extra $\mathrm{N}$ supply that occurs with starter inclusion. Usually, the efficiency of extra $\mathrm{N}$ is lower than the $\mathrm{N}$ efficiency of the base diet. Thus, the efficiency of $\mathrm{N}$ deposition declines (Gerrits et al., 1997). However, this fact can be related with the AA balance in the diet, because protein deposition is directly linked to the quality of protein source used in the diet (Oldham, 1987).

\section{CONCLUSIONS}

Based on the results found in this study and in the literature, it can be concluded that starter feed must be used in all situations in dairy suckling calves, independent of milk amount supplied. However, from a research viewpoint, further studies should be done testing the presence or absence of starter feed to evaluate other situations, such as using milk replacer. Although low milk allowances result in an elevated starter feed intake, they are associated with poor performances because animals are incapable to compensate nutrient deficits in diet by increasing starter intake. Thus, low amounts of milk should not be supplied to animals, especially during the first weeks of life. Conversely, high amounts of milk are also associated with greater fat deposition in the EBW of calves, which may represent a risk to the development of the mammary gland of heifers if the supply is extended beyond $60 \mathrm{~d}$ of life. 


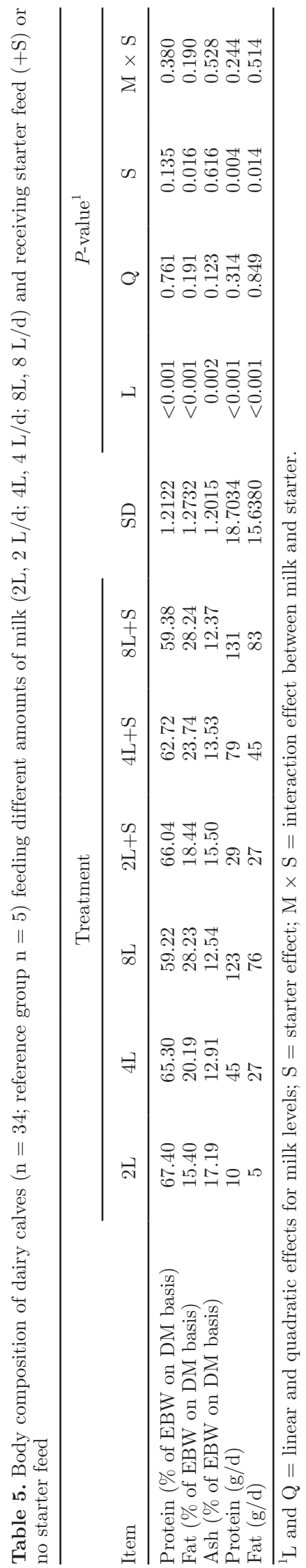

\section{ACKNOWLEDGMENTS}

We are grateful to the Brazilian foundations Coordenação de Aperfeiçoamento de Pessoal de Nível Superior (CAPES), Conselho Nacional de Desenvolvimento Científico e Tecnológico (CNPq), Fundação de Amparo à Pesquisa do estado de Minas Gerais (FAPEMIG), Instituto Nacional de Ciência e Tecnologia de Ciência Animal (INCT-CA), and Empresa Brasileira de Pesquisa Agropecuária (EMBRAPA-Gado de Leite) for their help in this study.

\section{REFERENCES}

AOCS (American Oil Chemists Society). 2009. Rapid determination of oil/fat utilizing high temperature solvent extraction. Accessed Jul. 05, 2013. https://ankom.com/media/documents/crudefat_0504_013009.pdf. American Oil Chemists Society, Urbana, IL.

AOAC International. 1995. Official Methods of Analysis. 16th ed. AOAC International, Arlington, VA.

Bach, A. 2012. Ruminant nutrition symposium: Optimizing performance of the offspring: Nourishing and managing the dam and postnatal calf for optimal lactation, reproduction, and immunity. J. Anim. Sci. 90:1835-1845. http://dx.doi.org/10.2527/jas.20114516.

Bach, A., M. Terré, and A. Pinto. 2013. Performance and health responses of dairy calves offered different milk replacer allowances. J. Dairy Sci. 96:7790-7797. http://dx.doi.org/10.3168/jds.20136909.

Barbosa, A. M., R. F. D. Valadares, S. C. Valadares Filho, R. M. L. Véras, M. I. Leão, E. Detmann, M. F. Paulino, M. I. Marcondes, and M. A. Souza. 2006. Efeito do período de coleta de urina, dos níveis de concentrado e de fontes protéicas sobre a excreção de creatinina, de uréia e de derivados de purina e a produção microbiana em bovinos Nelore. R. Bras. Zootec. 35:870-877.

Bascom, S. A., R. E. James, M. L. McGilliard, and M. Van Amburgh. 2007. Influence of dietary fat and protein on body composition of Jersey bull calves. J. Dairy Sci. 90:5600-5609. http://dx.doi. org/10.3168/jds.2007-0004.

Bittar, C. M. M., L. S. Ferreira, F. A. P. Santos, and M. Zopollatto. 2009. Desempenho e desenvolvimento do trato digestório superior de bezerros leiteiros alimentados com concentrado de diferentes formas físicas. R. Bras. Zootec. 38:1561-1567. http://dx.doi. org/10.1590/S1516-35982009000800021.

Blome, R. M., J. K. Drackley, F. K. Mckeith, M. F. Hutjens, and G. C. Mccoy. 2003. Growth, nutrient utilization, and body composition of dairy calves fed milk replacers containing different amounts of protein. J. Anim. Sci. 81:1641-1655.

Brown, E. G., M. J. Vandehaar, K. M. Daniels, J. S. Liesman, L. T. Chapin, D. H. Keisler, and M. S. W. Nielsen. 2005. Effect of increasing energy and protein intake on body growth and carcass composition of heifer calves. J. Dairy Sci. 88:585-594. http:// dx.doi.org/10.3168/jds.S0022-0302(05)72722-3.

Detmann, E., M. A. Souza, and S. C. Valadares Filho. 2012. Métodos para Análises de Alimentos. 1st ed. E. Detmann, M.A. Souza, and S.C. Valadares Filho, ed. Suprema, Visconde do Rio Branco, Brazil.

Detmann, E., and S. C. Valadares Filho. 2010. On the estimation of non-fibrous carbohydrates in feeds and diets. Arq. Bras. Med. Vet. Zootec. 62:980-984.

Diaz, M. C., M. E. Van Amburgh, J. M. Smith, J. M. Kelsey, and E. L. Hutten. 2001. Composition of growth of Holstein calves fed milk replacer from birth to 105-kilogram body weight. J. Dairy Sci. 84:830-842. http://dx.doi.org/10.3168/jds.S0022-0302(01)745419.

Drackley, J. K. 2008. Calf nutrition from birth to breeding. Vet. Clin. North Am. Food Anim. Pract. 24:55-86. 
Gerrits, W. J. J., J. France, J. Dijkstra, M. W. Bosch, G. H. Tolman, and S. Tamminga. 1997. Evaluation of a model integrating protein and energy metabolism in. J. Nutr. 127:1243-1252.

Hill, S. R., K. F. Knowlton, K. M. Daniels, R. E. James, R. E. Pearson, A. V. Capuco, and R. M. Akers. 2008. Effects of milk replacer composition on growth, body composition, and nutrient excretion in preweaned Holstein heifers. J. Dairy Sci. 91:3145-3155. http:// dx.doi.org/10.3168/jds.2007-0860.

Hill, T. M., H. G. Bateman, J. M. Aldrich, J. D. Quigley, and R. L. Schlotterbeck. 2013. Evaluation of ad libitum acidified milk replacer programs for dairy calves. J. Dairy Sci. 96:3153-3162. http://dx.doi.org/10.3168/jds.2012-6132.

Jasper, J., and D. M. Weary. 2002. Effects of ad libitum milk intake on dairy calves. J. Dairy Sci. 85:3054-3058. http://dx.doi. org/10.3168/jds.S0022-0302(02)74391-9.

Kertz, A. F., and J. R. Loften. 2013. Review: A historical perspective feeding programs in the United States and effects on eventual performance of Holstein dairy calves. Prof. Anim. Sci. 29:321-332.

Khan, M. A., H. J. Lee, W. S. Lee, H. S. Kim, K. S. Ki, T. Y. Hur, G. H. Suh, S. J. Kang, and Y. J. Choi. 2007a. Structural growth, rumen development, and metabolic and immune responses of Holstein male calves fed milk through step-down and conventional methods. J. Dairy Sci. 90:3376-3387. http://dx.doi.org/10.3168/ jds.2007-0104.

Khan, M. A., H. J. Lee, W. S. Lee, H. S. Kim, S. B. Kim, K. S. Ki, J. K. Ha, H. G. Lee, and Y. J. Choi. 2007b. Pre- and postweaning performance of holstein female calves fed milk through step-down and conventional methods. J. Dairy Sci. 90:876-885. http:// dx.doi.org/10.3168/jds.S0022-0302(07)71571-0.

Khan, M. A., D. M. Weary, and M. A. G. von Keyserlingk. 2011. Invited review: Effects of milk ration on solid feed intake, weaning, and performance in dairy heifers. J. Dairy Sci. 94:1071-1081. http://dx.doi.org/10.3168/jds.2010-3733.

Knowlton, K. F., M. L. McGilliard, Z. Zhao, K. G. Hall, W. Mims, and M. D. Hanigan. 2010. Effective nitrogen preservation during urine collection from Holstein heifers fed diets with high or low protein content. J. Dairy Sci. 93:323-329. http://dx.doi.org/10.3168/ jds.2009-2600.

Kosiorowska, A., L. Puggaard, M. S. Hedemann, J. Sehested, S. K. Jensen, N. B. Kristensen, P. Kuropka, K. Marycz, and M. Vestergaard. 2011. Gastrointestinal development of dairy calves fed low- or high-starch concentrate at two milk allowances. Animal 5:211-219. http://dx.doi.org/10.1017/S1751731110001710.

Kristensen, N. B., J. Sehested, S. K. Jensen, and M. Vestergaard. 2007. Effect of milk allowance on concentrate intake, ruminal environment, and ruminal development in milk-fed Holstein calves. J. Dairy Sci. 90:4346-4355. http://dx.doi.org/10.3168/jds.2006-885.

Labussiere, E., S. Dubois, J. van Milgen, G. Bertrand, and J. Noblet. 2008. Effects of dietary crude protein on protein and fat deposition in milk-fed veal calves. J. Dairy Sci. 91:4741-4754. http://dx.doi. org/10.3168/jds.2008-1203.

Miller-Cushon, E. K., R. Bergeron, K. E. Leslie, and T. J. DeVries. 2013. Effect of milk feeding level on development of feeding behavior in dairy calves. J. Dairy Sci. 96:551-564. http://dx.doi. org/10.3168/jds.2012-5937.

Mills, J. K., D. A. Ross, and M. E. Van Amburgh. 2010. The effects of feeding medium-chain triglycerides on the growth, insulin responsiveness, and body composition of Holstein calves from birth to $85 \mathrm{~kg}$ of body weight. J. Dairy Sci. 93:4262-4273. http://dx.doi. org/10.3168/jds.2010-3142.

Moallem, U., D. Werner, H. Lehrer, M. Zachut, L. Livshitz, S. Yakoby, and A. Shamay. 2010. Long-term effects of ad libitum whole milk prior to weaning and prepubertal protein supplementation on skeletal growth rate and first-lactation milk production. J. Dairy Sci. 93:2639-2650. http://dx.doi.org/10.3168/jds.2009-3007.
Nascimento, M. L., M. F. Paulino, E. Detmann, M. I. Leão, S. C. Valadares Filho, and L. T. Henriques. 2010. Fontes de energia em suplementos múltiplos para novilhos em pastejo durante o período das águas. R. Bras. Zootec. 39:861-872.

NRC. 2001. Nutrient Requirements of Dairy Cattle. 7th ed. Natl. Acad. Press, Washington, DC.

Oldham, J. D. 1987. Efficiencies of amino acid utilization. Pages 171-186 in Feed Evaluation and Protein Requirement Systems for Ruminants. R. Jarrige and G. Alderman, ed. Commission of the European Communities, Brussels, Belgium.

Piantoni, P., K. M. Daniels, R. E. Everts, S. L. Rodriguez-Zas, H. A. Lewin, W. L. Hurley, R. M. Akers, and J. J. Loor. 2012. Level of nutrient intake affects mammary gland gene expression profiles in preweaned Holstein heifers. J. Dairy Sci. 95:2550-2561. http:// dx.doi.org/10.3168/jds.2011-4539.

Santos, S. A., J. M. S. Campos, S. C. Valadares Filho, A. S. Oliveira, S. M. Souza, and A. M. F. Santiago. 2010. Balanço de nitrogênio em fêmeas leiteiras em confinamento alimentadas com concentrado à base de farelo de soja ou farelo de algodão. R. Bras. Zootec. 39:1135-1140. http://dx.doi.org/10.1590/S151635982010000500026.

SAS Institute. 2008. SAS/STAT 9.2 User's Guide. SAS Institute Inc., Cary, NC

Silper, B. F., A. M. Q. Lana, A. U. Carvalho, C. S. Ferreira, A. P. S Franzoni, J. A. M. Lima, H. M. Saturnino, R. B. Reis, and S. G. Coelho. 2014. Effects of milk replacer feeding strategies on performance, ruminal development, and metabolism of dairy calves. J. Dairy Sci. 97:1016-1025. http://dx.doi.org/10.3168/jds.20137201.

Silva, L. F. P., M. J. VandeHaar, B. K. Whitlock, R. P. Radcliff, and H. A. Tucker. 2002. Short communication: relationship between body growth and mammary development in dairy heifers. J. Dairy Sci. 85:2600-2602. http://dx.doi.org/10.3168/jds.S00220302(02)74344-0.

Soberon, F., E. Raffrenato, R. W. Everett, and M. E. Van Amburgh. 2012. Preweaning milk replacer intake and effects on long-term productivity of dairy calves. J. Dairy Sci. 95:783-793. http:// dx.doi.org/10.3168/jds.2011-4391.

Stanley, S., K. Wynne, B. McGowan, and S. Bloom. 2005. Hormonal regulation of food intake. Physiol. Rev. 85:1131-1158. http:// dx.doi.org/10.1152/physrev.00015.2004.

Sweeney, B. C., J. Rushen, D. M. Weary, and A. M. Passillé. 2010. Duration of weaning, starter intake, and weight gain of dairy calves fed large amounts of milk. J. Dairy Sci. 93:148-152. http:// dx.doi.org/10.3168/jds.2009-2427.

Talke, H., and G. E. Schubert. 1965. Enzymatic urea determination in the blood and serum in the Warburg optical test. Klin. Wochenschr. 43:174 http://dx.doi.org/10.1007/BF01484513.

Terré, M., C. Tejero, and A. Bach. 2009. Long-term effects on heifer performance of an enhanced-growth feeding programme applied during the preweaning period. J. Dairy Res. 76:331-339. http:// dx.doi.org/10.1017/S0022029909004142.

Van Soest, P. J. 1994. Nutritional Ecology of the Ruminant. Cornell University Press, Ithaca, NY.

Véras, R. M. L., S. C. Valadares Filho, R. F. D. Valadares, L. N. Rennó, P. V. R. Paulino, and M. A. Souza. 2007. Balanço de compostos nitrogenados e estimativa das exigências de proteína de mantença de bovinos Nelore de três condições sexuais. R Bras. Zootec. 36:1212-1217. http://dx.doi.org/10.1590/S151635982007000500030.

Wenge, J., I. Steinhöfel, C. Heinrich, M. Coenen, and L. Bachmann. 2014. Water and concentrate intake, weight gain and duration of diarrhea in young suckling calves on different diets. Livest. Sci. 159:133-140. http://dx.doi.org/10.1016/j.livsci.2013.11.004. 